\title{
PENGARUH PENAMBAHAN TEPUNG BENGKUANG TERHADAP KADAR KALSIUM SUSU KEDELAI
}

\author{
Ambarwani $^{1}$, Destyna Mahanany ${ }^{2}$, Dipicha Triesnaputri K. W' \\ dan Pramudya Kurnia ${ }^{2}$ \\ ${ }^{1}$ Bagian Gizi Puskesmas Majegan \\ Jl. Jatinom-Boyolali, Tulung, Klaten \\ ${ }^{2}$ Prodi Gizi Fakultas IImu Kesehatan Universitas Muhammadiyah Surakarta
}

\begin{abstract}
Calcium deficiency in adolescence and early adulthood may increase risk of osteoporosis. The prevalence of osteoporosis of Indonesia population in 2005 was 10.3\%, whereas for young people (below 25 years) was $37.1 \%$, and for young adult women was 39.5\%. One way to prevent osteopenia and osteoporosis is to consume cow's milk. The problem is the high price of cow's milk, so the other alternative is soy milk. The calcium of soy milk, however, is lower than cow's milk. Yam is tuber that is rich in calcium and phosphorus. The completely random design was used with 4 treatments of yam flour added to soy milk, were $0 \%$ (control), $2.5 \%, 5 \%$, and $7.5 \%$. The calcium content was determined using AAS. Data were analyzed using anova, followed by Duncan. The result displayed that optimum of calcium content was indicated by addition of yam flour $5 \%$. The conclusion is there is the effect of yam flour addition on calcium level of soy milk.
\end{abstract}

Keywords: Soy Milk, Yam Flour, Calcium.

\section{PENDAHULUAN}

Kedelai di Indonesia, menjadi sumber gizi protein nabati utama. Pemanfaatan utama kedelai adalah dari biji. Biji kedelai kaya protein dan lemak, serta beberapa bahan gizi penting lain misalnya vitamin, asam fitat dan lesitin.

Kedelai dapat diolah menjadi berbagai bahan makanan. Salah satu olahan biji kedelai adalah susu kedelai. Mutu protein dalam susu kedelai hampir sama dengan mutu protein susu sapi. Protein efisiensi rasio (PER) susu kedelai adalah 2,3 sedangkan PER susu sapi 2,5. PER 2,3 artinya, setiap gram protein yang dimakan akan menghasilkan pertambahan berat badan pada hewan percobaan (tikus putih) sebanyak 2,3 g pada kondisi percobaan baku (Koswara, 2006).

Kelebihan susu kedelai dikarenakan susu ini tidak mengandung laktosa sehingga susu ini cocok dikonsumsi oleh penderita intoleransi laktosa, yaitu seseorang yang tidak mempunyai enzim lactase dalam tubuhnya (Cahyadi, 2007). Sehingga 
susu kedelai dapat dijadikan alternatif pengganti susu sapi bagi orang-orang yang alergi terhadap susu sapi.

Selain kelebihan, susu kedelai juga mempunyai kelemahan, yaitu mempunyai bau dan rasa langu serta kurang mengandung kalsium. Kandungan kalsium susu kedelai hanya sekitar sepertiga susu sapi (Atmarita, 2005), sedangkan dari penelitian Yuwono dan Susanto (2006), diketahui bahwa kadar kalsium susu kedelai yang terbuat dari perbandingan kedelai dengan air, 1:10 dengan metode Atomic Absostion Spektrophotometry (AAS) adalah 15,65 ppm.

Kalsium bersama-sama fosfor merupakan mineral utama penyusun tulang. Kekurangan kalsium di masa remaja dan dewasa awal akan meningkatkan risiko osteoporosis (Spear, 2004). Wijayakusuma (2011), menyatakan bahwa osteoporosis merupakan penyakit tulang yang ditandai dengan rendahnya masa tulang, yang diantaranya disebabkan karena kalsium dan elemen dari tulang berkurang secara abnormal sehingga tulang menjadi rapuh, keropos dan mudah patah.

Prevalensi osteoporosis penduduk Indonesia tahun 2005 adalah 10,3\% dan penderita osteopenia atau penurunan massa tulang dini mencapai 41,7\% (Pusat Penelitian dan Pengembangan Gizi dan Makanan Depkes RI dan PT Fonterra Brands, 2005). Rachmawati (2006), menyatakan bahwa osteopenia juga menyerang kaum muda yang berumur kurang dari 25 tahun dengan prevalensi $37,1 \%$. Hermastuti dan Isnawati (2012), menyatakan bahwa $39,5 \%$ wanita dewasa muda umur 18 - 23 tahun mengalami osteopenia. Berdasarkan penelitian Hardinsyah dkk (2008), menunjukkan adanya kecenderungan bahwa siswa yang mengalami defisiensi kalsium juga mempunyai densitas tulang yang rendah. Oleh karena itu dianjurkan penambahan atau fortifikasi mineral terutama kalsium pada susu kedelai.

Bengkuang merupakan salah satu jenis umbi-umbian yang dapat langsung dimakan. Pada umumnya umbi bengkuang digunakan sebagai campuran bahan rujak dan produk kecantikan. Selain itu bengkuang juga mengandung mineral tinggi. Mineral yang terkandung dalam bengkuang yang paling dominan adalah fosfor dan kalsium. Kandungan fosfor dan kalsium pada bengkuang per 100 gram BDD adalah $18 \mathrm{mg}$ dan $15 \mathrm{mg}$ (Atmarita, 2005). Penelitian yang dilakukan Nurrochmad, et al (2010), menunjukkan bahwa fitoestrogen yang terkandung dalam bengkuang dapat meningkatkan femur dan fibiya, kepadatan tulang belakang dan kandungan kalsium serta fosfat pada tulang belakang.

Berdasarkan penelitian Rosa (2010), diketahui bahwa penambahan tepung dan pati garut yang digunakan dalam pembuatan yoghurt adalah $0 \%$, $2,5 \%, 5 \%, 7,5 \%$ dan $10 \%$. Adapun hasil 
dari penelitian tersebut adalah bahwa yoghurt yang paling disukai yaitu yoghurt dengan penambahan garut (baik tepung maupun pati) sebesar $5 \%$. Oleh karena pada penelitian ini menggunakan penambahan tepung bengkuang $0 \%, 2,5 \%, 5 \%$ dan $7,5 \%$ dengan 2 kali ulangan.

Winarno (2004), menyatakan bahwa proses pencoklatan (browning) sering terjadi pada proses pembuatan tepung bengkuang baik secara enzimatis maupun non enzimatis yaitu pada saat pemotongan dan pengeringan umbi. Salah satu cara yang dapat digunakan untuk mencegah atau mengurangi terjadinya browning adalah metode blancing. Blanching adalah proses perlakuan pemanasan awal yang biasanya dilakukan pada bahan nabati segar sebelum mengalami proses pengolahan lebih lanjut misalnya pembekuan, pengeringan atau pengalengan. Blancing biasanya dilakukan dengan memanaskan bahan makanan pada suhu kurang dari $100^{\circ} \mathrm{C}$. Salah satu cara blancing bahan makanan adalah dimasukkan pada air panas suhu $80^{\circ} \mathrm{C}$ selama satu menit, kemudian dilanjutkan dengan proses pendinginan pada air es selama beberapa waktu (Zaifbio, 2013).

Berdasarkan latar belakang masalah, penulis tertarik untuk meneliti tentang pengaruh penambahan tepung bengkuang terhadap kadar kalsium susu kedelai. Tujuan penelitian ini adalah untuk mengetahui kadar kalsium susu kedelai dengan penambahan tepung bengkuang

\section{METODE PENELITIAN}

Penelitian ini merupakan penelitian eksperimental, karena peneliti memberi perlakuan dan dampaknya akan diamati atau diukur kemudian.

Penelitian ini dilaksanakan di Laboratorium Ilmu Teknologi Pangan Universitas Muhammadiyah Surakarta dan Laboratorium kimia dan kesuburan tanah Fakultas Pertanian Universitas Sebelas Maret Surakarta. Sedangkan waktunya dari Bulan April 2012 sampai dengan Mei 2013.

Variabel dalam penelitian ini adalah: Variabel bebas : penambahan tepung bengkuang pada susu kedelai dan variabel terikat : kadar kalsium susu kedelai

Alat yang digunakan pada penelitian ini adalah: Alat pembuatan tepung bengkuang dan susu kedelai : panci, dandang, pengaduk/ irus, kain penyaring, oven, pengayak/ saringan tepung, timbangan, blender, termometer, arloji dan kompor. Sedangkan alat untuk analisa kadar kalsium dengan metode AAS : alat AAS (merk SHIMADZU, type AA-6200, dibaca pada panjang gelombang 422,7 $\mathrm{nm}$ ), waterbath, tabung reaksi, rak tabung, gelas ukur, pipet volum, pipet filter, pipet tetes dan batang pengaduk.

Bahan untuk pembuatan susu kedelai adalah : Kedelai kuning yang diperoleh dari pasar tradisional, Desa 
Bono, Tulung, Klaten. Bengkuang diperoleh dari pasar tradisional Kartasura, Surakarta. Bahan lain adalah gula pasir dan garam.
Jumlah kedelai, tepung bengkuang, gula pasir dan air yang digunakan dalam pembuatan susu kedelai disajikan pada Tabel 1.

Tabel 1. Komposisi Perlakuan pada Pembuatan Susu Kedelai

\begin{tabular}{lcccc}
\hline \multirow{2}{*}{ Bahan Makanan } & \multicolumn{4}{c}{ Penambahan Tepung Bengkuang } \\
\cline { 2 - 5 } & $\begin{array}{c}0 \% \\
(\text { gram })\end{array}$ & $\begin{array}{c}2,5 \% \\
(\text { gram })\end{array}$ & $\begin{array}{c}5 \% \\
(\text { gram })\end{array}$ & $\begin{array}{c}7,5 \% \\
(\text { gram })\end{array}$ \\
\hline Kedelai & 250 & 250 & 250 & 250 \\
Tepung Bengkuang & 0 & 6,25 & 12,5 & 18,75 \\
Gula (7\%) & 157,5 & 157,5 & 157,5 & 157,5 \\
Garam (0,45\%) & 10,13 & 10,13 & 10,13 & 10,13 \\
Air $(1: 9)$ & $2250 \mathrm{ml}$ & $2250 \mathrm{ml}$ & $2250 \mathrm{ml}$ & $2250 \mathrm{ml}$ \\
\hline
\end{tabular}

Bahan untuk analisa kadar kalsium susu kedelai (masing -masing $1 \mathrm{ml}$ untuk satu sampel): gas neon atau argon, larutan standar $\mathrm{Ca}^{2+}$, asam nitrat pekat $\left(\mathrm{HNO}_{3}\right)$ dan asam perkhlorat $\left(\mathrm{HClO}_{4}\right)$.

Rancangan percobaan ini adalah Rancangan Acak Lengkap (RAL). Terdapat empat macam perlakuan dengan dua kali ulangan, sehingga terdapat $4 \times 2=8$ perlakuan. Penambahan tepung bengkuang yang digunakan adalah $0 \%, 2,5 \%, 5 \%$ dan 7,5\%.

Cara kerja pembuatan tepung bengkuang: Pembuatan tepung bengkuang ini didasarkan pada pembuatan tepung ubi jalar menurut Heriyanto et al., (2001) dalam Damayanti (2010), dengan modifikasi perendaman dengan larutan natrium metabisulfit diganti dengan blancing dan suhu pengeringan dari $60^{\circ} \mathrm{C}$ selama 5 jam menjadi $70^{\circ} \mathrm{C}$ selama 17 jam, alat oven diganti dengan drum dryer.
Adapun langkah - langkah pembuatan tepung bengkuang adalah sebagai berikut : Bengkuang dikupas, kemudian dicuci bersih, kemudian diparut dengan parut sawut, setelah itu bengkuan parut diblancing pada suhu $80^{\circ} \mathrm{C}$, selama 1 menit. Langkah selanjutnya bengkuang sawut direndam pada air es, kemudian ditiriskan dan dikeringkan dengan drum dryer pada suhu $70^{\circ} \mathrm{C}$ selama \pm 17 jam. Kemudian bengkuang sawut yang telah kering digiling dengan blender, langkah terakhir bengkuang giling diayak hingga diperoleh tepung bengkuang

Pembutan susu kedelai didasarkan pada cara pembuatan susu kedelai oleh kantor deputi menegristek bidang pendayagunaan dan pemasyarakatan ilmu pengetahuan dan teknologi dengan sedikit modifikasi, yaitu sebagai berikut: Kedelai dibersihkan dari segala kotoran, kemudian direndam selama 24 jam, lalu dikupas, dicuci dan 
dibilas. Langkah selanjutnya kedelai yang telah bersih dikukus selama \pm 10 menit pada kondisi air mendidih dan diblender dengan perbandingan kedelai dan air 1 : 9. Setelah itu campuran disaring dengan kain saring, hingga diperoleh susu kedelai mentah. Tepung bengkuang ditambahkan ke dalam susu kedelai mentah. Selanjutnya susu kedelai mentah dipanaskan, kemudian ditambah gula pasir dan garam, diaduk sampai rata dan dipanaskan sampai mendidih, selama 15 menit. Langkah terakhir susu dipasteurisasi pada suhu $90^{\circ} \mathrm{C}$ selama 15 menit

\section{HASIL DAN PEMBAHASAN}

Susu kedelai yang dibuat pada penelitian ini menggunakan bahan utama kedelai dengan penambahan tepung bengkuang. Fungsi penggunaan tepung bengkuang adalah untuk meningkatkan kandungan kalsium susu kedelai. Kandungan kalsium bengkuang per 100 gram BDD adalah $15 \mathrm{mg}$ (Atmarita, 2005). Rendemen tepung bengkuang pada penelitian ini adalah sebanyak 40 gram dari sebanyak $1,5 \mathrm{~kg}$ bengkuang segar. Nurrochmad, et al, (2010), menyatakan bahwa Fitoestrogen yang terkandung dalam bengkuang dapat meningkatkan femur dan fibiya, kepadatan tulang belakang dan kandungan kalsium serta fosfat pada tulang belakang.

Hasil analisis kadar kalsium susu kedelai dengan penambahan tepung bengkuang disajikan pada Tabel 2.

Tabel 2. Kadar Kalsium Susu Kedelai dengan Penambahan Tepung Bengkuang

\begin{tabular}{cc}
\hline Penambahan Tepung Bengkuang & Rata-rata Kadar Kalsium \pm SD $(\mathrm{ppm})$ \\
\hline $0 \%$ (kontrol)) & $23,800 \pm 0,042$ \\
$2,5 \%$ & $38,010 \pm 15,71$ \\
$5 \%$ & $54,095 \pm 0,459$ \\
$7,5 \%$ & $49,175 \pm 0,078$ \\
Nilai Sig $(\mathrm{p})$ & 0,060 \\
\hline
\end{tabular}

Berdasarkan Tabel 2 dapat diketahui bahwa kadar kalsium tertinggi terdapat pada susu kedelai dengan penambahan tepung bengkuang $5 \%$ dengan nilai rata-rata 54,095 ppm dan terendah pada penambahan tepung bengkuang $0 \%$ (kontrol), dengan nilai rata-rata 23,800 ppm. Dari hasil uji
Anova nilai $\mathrm{p}=0,060(>0,05)$, menunjukkan tidak terdapat perbedaan yang signifikan antara kontrol dengan kelompok perlakuan, namun demikian terlihat bahwa nilai rata-rata kelompok perlakuan lebih tinggi dari pada kontrol. Hal ini disebabkan karena adanya kandungan kalsium pada tepung 
bengkuang. Penelitian ini sejalan dengan penelitian Yuwono dan Susanto (2006), bahwa pada pembuatan susu kedelai dengan perbandingan kedelai dengan air, 1:10, diketahui bahwa kandungan kalsiumnya adalah
15,65 ppm.

Adapun grafik uji kadar kalsium pada susu kedelai dengan penambahan tepung bengkuang terdapat pada Gambar 1.

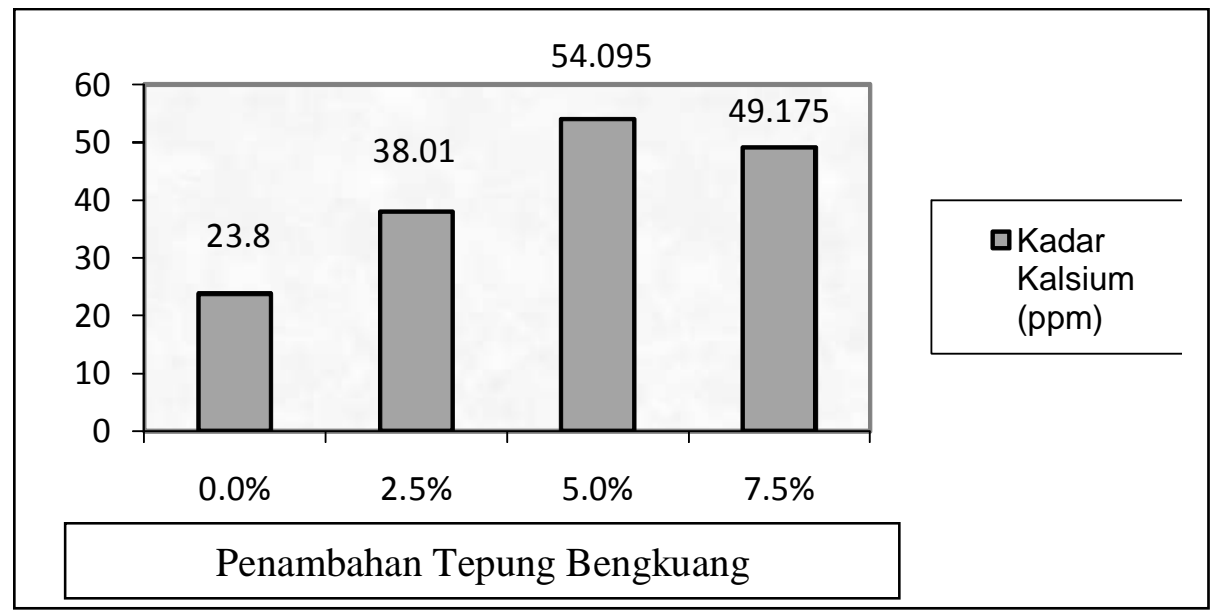

Gambar 1. Grafik Uji Kadar Kalsium Susu Kedelai

\section{KESIMPULAN DAN SARAN}

\section{A. Kesimpulan}

Kadar kalsium tertinggi adalah pada perlakuan susu kedelai dengan penambahan tepung bengkuang $5 \%$, yaitu sebanyak 54,095 ppm.

\section{B. Saran}

Susu kedelai dengan penambahan tepung bengkuang $5 \%$ dapat digunakan sebagai alternatif susu kedelai dengan kandungan kalsium yang lebih tinggi.

\section{UCAPAN TERIMA KASIH}

Terima kasih penulis ucapkan kepada Fakultas Ilmu Kesehatan Universitas Muhammadiyah Surakarta yang telah mendanai penelitian ini lewat program Hibah Penelitian Fakultas. 


\section{DAFTAR PUSTAKA}

Atmarita (ed), 2005, Daftar Komposisi Bahan Makanan (DKBM), Persagi Indonesia, Jakarta

Cahyadi,W., 2007, Teknologi dan Khasiat Kedelai, Bumi Aksara, Jakarta

Hardinsyah, Damanyanthi, E. dan Zulianti, W., 2008. Hubungan Konsumsi Susu dan Kalsium dengan Densitas Tulang dan Tinggi Badan Remaja. Junal Gizi dan Pangan. 3 (1) : 43 - 48.

Hermastuti, A. dan Isnawati, M. 2012. Hubungan IMT, Massa Lemak Tubuh, Asupan Kalsium, Aktivitas Fisik dan Kepadatan Tulang pada Wanita Dewasa Muda. Journal of Nutrition College. Vol 1 (1). Hal : 435 - 450

Kantor Deputi Menegristek Bidang Pendayagunaan dan Pemasyarakatan Ilmu Pengetahan dan Teknologi, 2000, Susu Kedelai, http:/ / ww.warintek.ristek. go.id, diakses 15 Februari 2012

Koswara, S. 2006. Susu Kedelai Tak Kalah dengan Susu Sapi. Diakses : 15 Februari 2012. http:/ / www.ebookpangan.com.

Nurrochmad, A., leviana, F., Wulancarsari, C. G. dan Lukitaningsih, E., 2010. Phytoestrogens of Pachyrhizus erosus prevent Bone loss in an Ovariectomized Rat Model of Osteoporosis. International Journal of Phytomedicine, 2 : 363-372

Pusat Penelitian dan Pengembangan Gizi dan Makanan Depkes RI dan PT Fonterra Brands Indonesia. 2005. Prevalensi Osteopoosis dan Osteopenia. Bogor

Rachmawati, E. 2006. Saat Pencui Tulang Mengintai. Diakses : 23 Maret 2013. http:/ /kompas.com/ver1/kesehatan/0609/15

Rosa, Navila., 2010, Pengaruh Penambahan Umbi Garut (Maranta arundinaceae L) dalam Bentuk Tepung dan Pati sebagai Prebiotik pada Yoghurt sebagai Produk Sinbiotik Terhadap Daya Hambat Bakteri (Artikel Penelitian)

Spear, B, A. 2004. Nutrition in Adolescence. dalam Mahan, K dan Stump, S, E (Eds). Food, Nutrition and Diet Therapy. 11th ed. Saunders, Pennsylvania. hlm : 284-301

Wijayakusuma, H., 2011. Mencegah Osteoporosis dengan Pola Hidup Sehat. Diakses : 21Juli 2013. http:/ / www.itokindo.org

Winarno, FG., 2004, Kimia Pangan dan Gizi, PT. Gramedia Pustaka Utama, Jakarta 
Yuwono, SS dan Susanto, T. 2006. Pengaruh Perbandingan Kedelai : Air pada Proses Ekstraksi terhadap Ekstrakta bilitas Padatan Protein dan Kalsium Kedelai serta Rasio Fraksi Protein 75/115. Jurnal Teknologi Pertanian 7 (2) : 71-77.

Zaifbio, 2013. Proses Blanching pada Industri Pangan, Diakses : 07 April 2013. http:// zaifbio.wordpress.com/2013/01/01/ proses-blanching-pada-industripangan-2/ 